\title{
Factores que afectan la explicación educativa del desempeño de la red de ventas en la industria de seguros iraní
}

\section{Meta-synthesis of factors affecting the explanation of sales network performance in the Iranian insurance industry}

\author{
Hashem Daghighi Asli ${ }^{1}$, Kambiz Shahroodi ${ }^{2 a}$, Seyed Mozaffar Mirbarg Kar $^{3}$, \\ Yalda Rahmati ${ }^{4}$
}

Islamic Azad University, Rasht, Iran ${ }^{1234}$

iD Orcid ID: https://orcid.org/0000-0002-7308-1358

Orcid ID: https://orcid.org/0000-0001-6392-2799²

Orcid ID: https://orcid.org/0000-0002-2179-9662 3

Orcid ID: https://orcid.org/0000-0002-4270-71654

Recibido: 19 de abril de 2020

Aceptado: 10 de octubre de 2020

\section{Resumen}

El objetivo de este estudio fue la meta-síntesis de factores que afectan la explicación del desempeño de la red de ventas en la industria de seguros iraní. El método de esta investigación utilizando la teoría de datos, que es una de las mejores estrategias de investigación, a través de la cual; La teoría se basa en los conceptos principales de los datos. En este sentido, el método meta-combinado se ha utilizado sistemáticamente para recopilar y revisar estudios previos y el método de base de datos para proporcionar un modelo teórico. En la primera etapa, al integrar estrategias de búsqueda automática y manual, se cubren 25 artículos de investigación relacionados publicados en el alcance del desempeño de la red de ventas en la industria de seguros en el período 2009 a 2018 para artículos en inglés y de 2011 a 2018 para artículos persas. En la etapa final, luego de implementar los pasos propuestos por Glaser y Strauss, se presenta el modelo teórico propuesto. Los hallazgos de la investigación obtenidos de la primera etapa han mostrado que los factores psicológicos y conductuales tienen la mayor frecuencia en estudios previos y han prestado mayor atención, lo que de hecho enfoca estudios en el empoderamiento de los recursos humanos activos en la industria aseguradora. De acuerdo con los resultados factores individuales relacionados con los representantes y factores relacionados con la organización de los representantes, condiciones centrales que incluyen: desempeño del agente de seguros, condiciones estratégicas que incluyen: factores relacionados con el seguro central, condiciones del contexto predominante incluidas.

Palabras clave: Economía, servicios, seguros de vida, red de ventas, Irán

a Corresponding Author: E-mail: K_shahroodi@yahoo.com 


\begin{abstract}
The aim of this study was Meta-synthesis of factors affecting the explanation of sales network performance in the Iranian insurance industry. The method of this research using the data theory, which is one of the best research strategies, through which; Theory is based on the main concepts of the data. In this regard, the meta-combined method has been systematically used to collect and review previous studies and the foundation data method to provide a theoretical model. In the first stage, by integrating automatic and manual search strategies, 25 related research articles published in the scope of sales network performance in the insurance industry in the period 2009 to 2018 is covered for English articles and 2011 to 2018 for Persian articles. In the final stage, after implementing the proposed steps of Glaser and Strauss, the proposed theoretical model is presented. The results of the research obtained from the first stage have shown that psychological and behavioral factors have the highest frequency in previous studies and have paid the most attention, which in fact focuses studies on empowering human resources active in the insurance industry. According to the results individual factors related to representatives and factors related to the organization of representatives, central conditions including: performance of insurance agent, strategic conditions including: factors related to central insurance, prevailing context conditions included.
\end{abstract}

Keywords: Economy, services, life insurance, sales network, Iran

\title{
Introduction
}

Today, the service industry has a fundamental and important role in the economic development of countries and in the meantime, the important role of the insurance industry is not hidden from anyone (Di Giorgio et al, 2019). The importance of this industry is doubled because it can be introduced as one of the major economic institutions; rather, due to the supporting role that this industry plays for other industries, it introduced it as one of the symbols of developed countries (Sadat and Shafiee, 2016). Also, the insurance industry is one of the most important economic institutions and is considered one of the strongest support institutions for other economic institutions and households (Asadi and Hedayati, 2019). In fact, insurance companies are businesses that, like any other business, must make a profit for survival and development and making a profit depends on attracting and retaining customers and creating capable sales networks (Huang et al., 2016).

Due to the nature of the insurance industry, which covers the losses arising from the economic and development activities of society, causes a rapid movement of development in society (Ismailpour and Qasemnejad, 2018). And while; The annual reports of the Central Insurance of the Islamic Republic of Iran, as an institution supervising the insurance industry, show the declining profitability of the insurance industry in the mentioned fields. According to the same statistics, from 2008 to the end of 2017, the loss ratio of the third field was $97 \%$ on average. It is worth noting that the effect of administrative costs and fees paid by insurance companies is not included in this ratio. In health insurance, which has a significant share of the 
portfolio of insurance companies, the average loss ratio during the years 2007 to the end of 2017, excluding administrative costs and fees, has been reported 107 percent. These two disciplines account for the major share of claims paid by insurance companies. Published information of insurance companies indicates the weakness of appropriate decision-making in this area. Continuation of this trend can cause serious problems for insurance companies, which account for about 2.5\% of GDP (Khashei and Saboor, 2019).

The low rate of insurance penetration in Iran has various reasons, from popular culture and their lack of belief in insurance to the weakness of insurance companies in increasing this rate. Today, empowerment is considered as one of the useful tools to improve the quality of employees as well as sales representatives of the insurance industry and increase organizational effectiveness (Abbasi et al., 2016). Studies show that; incredibly, the impact of empowerment on organizations over the past decade has been noted by researchers and scientists (Voegtlin, 2015) the insurance industry is also one of the industries that has not escaped attention (MeskinNawaz et al., 2017). The insurance sales and marketing system consists of all executives (employees in insurance branches, brokers, agents), staff, infrastructure and software and hardware which should be managed according to a purposeful planning and based on marketing and sales skills (Shafei and Fathi, 2018). Insurance companies are increasingly increasing their representations to gain more share of the target market. Therefore, the level of ability of agencies in profitability is very decisive (MeskinNawaz et al., 2017).

In this regard, first of all, it is necessary to identify the factors affecting the performance of the sales network in the insurance industry in order to empower targeted agents. Because the study of statistics and performance of insurance industry sales network representatives shows that; almost all agents are not able to achieve these quantitative goals due to the goals set by the marketing and oversight unit of the insurance sales network. Another part of the representatives is not as satisfactory as it should be in relation to the market potential. Therefore, the sales of all types of insurance policies of these agents are very low or relatively low. Therefore, the present study seeks to answer the main question that; what factors determine the performance of the sales network in the insurance industry?

\section{Theoretical foundations and literature}

Insurance sales in the country are done in two ways: 1- Direct; 2- Indirect. In the direct method, the insurance company directly sells the insurance policy and marketing and selling through headquarters units and provincial and city branches. In the indirect method, the insurance policy is sold through the sales network. The pillars of the sales network are: Brokers 
who operate with a license and under the supervision of Central Insurance and while providing advice to the community and insurers are able to cooperate with all companies and sell insurance policies (Taebi and Rezvani, 2016).

It is necessary to mention the representatives and marketers in each area operate under the supervision of the company's branches in that area. Insurance is sold by the sales network, examination of his condition is extremely important and it should be done in such a way that marketing programs are included in this group and by recognizing their problems and resolving conflicts in the interests of the insurance company and the sales network, it is possible to try to enlarge the insurance influence network and create double motivation in the sales network and as a result promote the position of the insurance industry (Taebi and Rezvani, 2016).

In recent decades, increasing the penetration rate of insurance in Iran has been considered in the country. There are definitely a number of factors involved in increasing this index but in the meantime, the role of representatives as the executive arms of insurance companies and those who are at the forefront of sales and interaction with the customer is very important and for this reason, attracting the right sales force has always been one of the main concerns of the insurance industry and consequently insurance companies. Previous studies show; Personal characteristics of the sales force, which include characteristics such as personal motivation, self-esteem, ability to manage relationships and efficiency, are of significant importance in advancing the goals of companies (Nouri and Akbari, 2019). As the results of Taebi and Rezvani (2016) showed that; Factors such as manpower, sales outlets and agents increase the influence of insurance and the capability of the insurance sales network.

Individual factors are also among the variables affecting the empowerment of the insurance sales network. In 2019, Dinser et al. examined the relationship between the level of education of bank staff and their profitability; they studied information on 15 banks operating in Turkey from 2002 to 2006 and their resultss confirmed the relationship between staff education and bank profitability, these results indicate that; Turkish banks should focus more on attracting postgraduate and doctoral graduates when recruiting staff. The main reason for this is that; this group of staff is more capable than others due to the skills acquired during their studies at the university. Another important point is that; Banks do not have to spend a lot of money to increase the capacity of their staff in the workplace because these personnel have already acquired the required competencies during university. So, banks should instead focus on their payroll policies in order to attract university graduates to higher levels (Hasan Dinçer, et al., 2019). 


\section{Sales network position in insurance companies}

The position of the sales network in an industry depends to a large extent on the general approach of marketing activities in that industry, that is, it is the general marketing strategies of the industry that shape marketing practices. Therefore, knowing these general approaches can help design effective marketing systems (Groza et al, 2016).

One of the courses that the world insurance industry has experienced is the productoriented course. During this period, insurance companies invented insurance plans to their liking and offered them to the people, hoping that the people would buy them. Another period was the sales-oriented period, in which insurance companies hired a group of marketers to sell their insurance products. The third period was the period of customer orientation, in which insurance companies designed insurance policies based on the needs of the community and the fourth period was the market-oriented period in which the insurance industry with risk management tools tries to analyze the risks of insurers and produce insurance policies accordingly (Groza et al, 2016).

Despite going through the various stages above, in general, offering and providing insurance services like any other service in terms of its features is always more difficult than offering physical products and goods. It can be said that buying insurance requires a cultural background of insurance in the buyer to sell insurance. The buyer does not buy the insurance product until he knows it, that is, the primary and main task of the seller is to introduce the desired insurance to the buyer (Ismailpour, 2018).

Insurance sales network work is an infrastructure activity because it usually deals with people who do not have accurate and complete information about insurance services and to meet their insurance needs, they must be justified by this network. Insurance buyers need to know how to use it and what rights they get through this purchase and what responsibilities they take on and since this information must be provided by a representative, broker or insurance company, it is obvious that the seller must be sufficiently aware (Heikli, 2017).

Insurance agents and brokers and their marketers form the sales network of the insurance industry and in fact, the executive arms of insurance companies are for sale. The ability and growth of the sales network leads to sales progress in terms of quantity and quality, and its weakness will cause disturbances in the supply of insurance (Heikli, 2017).

Acquiring a customer alone will not be satisfying for an insurance company, in fact, with the sale of insurance, the work of the sales network begins and maintaining the customer and providing appropriate services in case of damage is the next step in the development of the monopoly market by insurance companies. 


\section{Table 1}

Summary of research and models for evaluating the performance of the insurance industry sales network

Model search

Insure Tech Innovation is a single market analysis based on Twitter data and a case study

Two-step approach (evaluation of technical and scale performance(

Dynamic two-stage dynamic data network (DEF) data analysis model with transfer variables based on dynamic slack with network structure Quasi-experimental design Forming a sales team: The right team model and control group

Fragility perspective - focus

\section{Combined MCDM model}

\section{Survey model}

Descriptive survey plan

Artificial neural networks and linear regression

Descriptive survey plan

\section{Descriptive survey plan}

Exploratory and using secondary research primary data Analytical study
Title

Investigating the characteristics and evolutionary capabilities of Insure tech innovations to understand the value of insurance in a digital world

Efficiency and productivity in private sector health insurers in Australia

Modeling investments in the dynamic network performance of insurance companies

members help the performance

Concentration and financial stability in the liability-property insurance sector: Global evidence

Financial modeling and planning improvement for the life insurance industry using vast knowledge based on the combined MCDM model

The Impact of Sales Strategies on the Financial Performance of Insurance Companies

Motivational strategies and sales force performance in the insurance industry in Kenya

Modeling and Evaluating Customer Loyalty Using Neural Networks: Evidence from Startup Insurance Companies

Relating Thinking Styles to Sales Performance: The Importance of Creativity and Mental Knowledge

Determinants of profitability of non-life insurance companies

Factors Affecting Life Insurance Absorption Rates: A Comparison Between Malaysia and Japan«

Relationship between Financial Planning and Life Insurance Consultants, Puneh, Maharashtra, India
Researcher

Stockley et al.

(2018)

Nguyen

Worthington

(2018)

Cauro et al. (2018)

Garrett and Gupalakrishna (2017)

Altontas and Bruch (2017)

Shen et al. (2017)

Maroufi et al. (2017)

Onyango (2017)

Ansari and Riyasi (2016)

Grozza et al. (2016)

Dare (2016)

Vijaranti and Ramsay (2016)

Disai (2016)

Source: Researcher Studies 


\section{Methodology}

In the present study, the data theory of the foundation has been used, which is one of the best research strategies, through which; Theory is based on the main concepts of the data. This means that the process of theory formation in this strategy is the movement from whole to part (Danaeifar et al., 2017). In this method, based on the proposed steps of Glaser and Strauss, the following steps are performed.

First step: Select the research topic: In this research, an attempt has been made to exploit a variety of signs and factors that can be useful and effective in identifying and defining the problem, personal experiences, researcher observations at different levels of work and management, as well as formal and informal reports of Central Insurance in the field of sales network performance in the insurance industry have been used in line with the research topic.

Second step: obtaining research goals: Glaser and Strauss (1967) have identified five main goals or applications for a foundation data research: Assess the validity of previous evidence, generalize based on experience, determine a unit of measurement for a single case study, verify the validity of existing theories, and generate a theory (theorizing) (Vaezi and Azmandian, 2016, 63). In this research, the aim is to theorize in the field of sales network performance in the insurance industry.

Third step: Select a group to study: In this research, based on the theoretical sampling procedure, insurance industry experts including the sales network of the insurance industry that have experience and higher education, technical and staff managers and major insurers have been interviewed. Qualifications for the interview include having at least a master's degree or at least 15 years of experience in the insurance industry. Therefore, after the review, 17 experts have been considered for specialized interviews. The research data at this stage has an exploratory aspect and completes and develops the researcher's observations.

Fourth step: Research data collection: In this section, a semi-structured questionnaire has been used to collect data. An iterative process that combines all of the existing research literature on a particular topic into an answer to a particular research question that the main purpose of this type of research method is to review, collect, summarize and evaluate evidence about a specific area (Ahmad et al., 2018). This method is done in order to discover any research gap in existing studies and in this way, a deeper insight and understanding of the phenomenon under study can be provided (Antercalmsteiner et al., 2012). Keithham and Chartres (2007) have shown that; this type of review research should consist of three stages, including planning, conducting, and reporting and each step has sub-elements, including: (1) Step 1: Formulate the research question; (2) Step 2: Systematic review of texts; (3) Step 3: 
Search and select appropriate articles; (4) Step 4: Extract textual information; (5) Step 5: Analysis and integration of qualitative results; And (6) Step 6: Quality Control. In this step, automatic search using keywords using string software for English sources was used and Noormags and Magiran for Persian sources 220 related research articles published in the field of sales network performance in the insurance industry in the period 2009 to 2018 for English articles and 2011 to 2018 for Persian articles are covered. Duplicate studies were performed using Mendeley software and finally the number of output articles in this section was 51 articles. Research is graded based on the 50-point Critical Assessment Skills Program Scale and researches with a score of less than 30 were eliminated and finally 25 suitable articles were identified.

Table 2

Criteria for inclusion and exclusion of scientific resources

\begin{tabular}{|c|c|}
\hline & Available in full text. \\
\hline & $\begin{array}{l}\text { English articles have been published for Persian articles in } \\
\text { the period between } 2009 \text { to } 2018 \text { and } 2011 \text { to } 2018 \text {. } \\
\text { Be in Persian and English. } \\
\text { Be in the field of sales network performance in the } \\
\text { insurance industry. }\end{array}$ \\
\hline $\begin{array}{l}\text { Criteria for exclusion (deletion) of } \\
\text { scientific resources }\end{array}$ & $\begin{array}{l}\text { Research with similar titles } \\
\text { Outside the set time frame } \\
\text { Lack of access to the full text of the article }\end{array}$ \\
\hline
\end{tabular}

\section{Step 5: Open coding and axial coding of the collected data}

In order to analyze the interviews, we first "open coded" each interview. We then categorize the extracted code into categories of "concepts" that have more general and abstract meanings than open source. Each of these concepts can be grouped into larger (more abstract) groups called “categories.” Therefore, after conceptualizing open source, the extracted concepts are categorized. It is necessary to mention; According to the procedure adopted in the data research method of the foundation, the mentioned categories of concepts and categories gradually become more coherent and complete by increasing the number of interviews and comparing the "continuous assessment” of previous results.

\section{Step 6: Selective data encoding}

The third step in coding is selective coding. At this stage, the researcher develops a theory among the categories obtained in the axial coding model. 


\section{Step 7: Theorizing (producing theory)}

\section{Results}

The study of research results begins with the fourth stage of data foundation theory (collection of research data) in this research, a system Meta-synthesis method has been used, the output of which is as described in Figure 1.

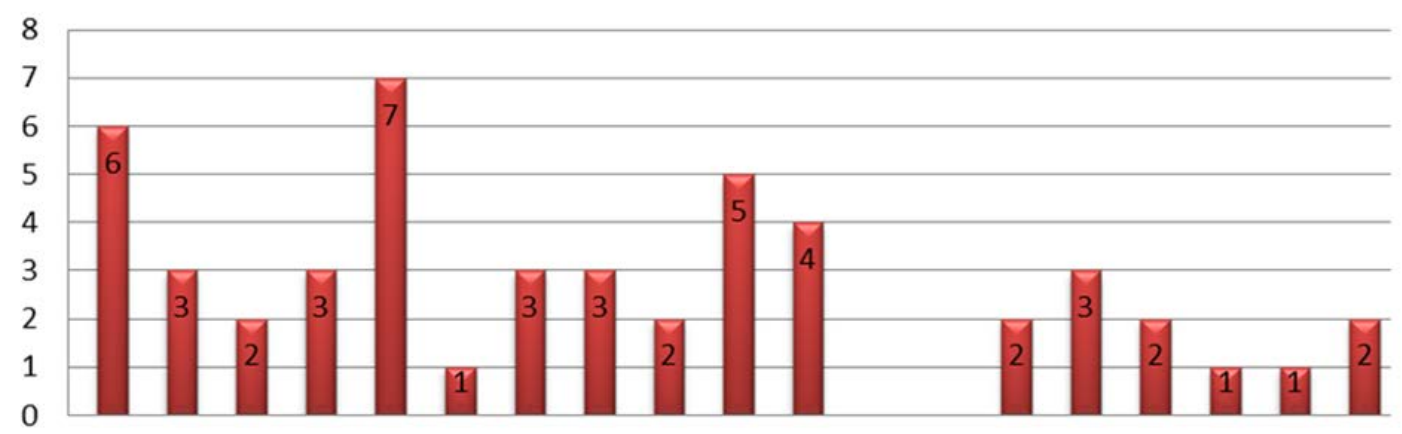

Fig 1

Collection of research data

The output of this table is the basis for designing a semi-structured interview text. In total interviews, the key point is marked with marker codes. These points are conceptualized in the form of abstract concepts. Explaining and establishing connections between concepts has shaped them into categories. Interviews are recorded between 40 and 100 minutes. The results of the analysis of the interviews (Steps 5 and 6 of the Foundation Data Theory) are shown in Table 3. 
Table 3

Integration of open coding, axial coding and selective coding steps

\begin{tabular}{|c|c|c|}
\hline $\begin{array}{l}\text { Main categories } \\
\text { (Selective coding) }\end{array}$ & $\begin{array}{l}\text { Subcategories } \\
\text { (Axial coding) }\end{array}$ & Open source (open source) \\
\hline \multirow{5}{*}{$\begin{array}{lr}\begin{array}{l}\text { Individual } \\
\text { related } \\
\text { representatives }\end{array} & \text { to } \\
\begin{array}{l}\text { Factors related to } \\
\text { organization } \\
\text { representatives }\end{array} & \text { of } \\
\end{array}$} & $\begin{array}{l}\text { Individual } \\
\text { characteristics }\end{array}$ & $\begin{array}{l}\text { Appearance / Having insurance knowledge / } \\
\text { Representative technical ability / Representative scientific } \\
\text { ability / Representative technical knowledge }\end{array}$ \\
\hline & $\begin{array}{l}\text { Organizational } \\
\text { characteristics }\end{array}$ & $\begin{array}{l}\text { Appropriate database of insurance policies / } \\
\text { Organizational status of the representative / Office location } \\
\text { / Appearance of the office / How to arrange the office / } \\
\text { Appropriate archive }\end{array}$ \\
\hline & $\begin{array}{l}\text { customer relation } \\
\text { management }\end{array}$ & $\begin{array}{l}\text { Timely advice to the customer / Accompanying the insurer } \\
\text { / Providing better customer service / The amount of time } \\
\text { spent with the customer / }\end{array}$ \\
\hline & $\begin{array}{l}\text { Characteristics of } \\
\text { human resources }\end{array}$ & $\begin{array}{l}\text { Having the right marketers / Having the best marketers / } \\
\text { Up-to-date knowledge of marketers / General knowledge } \\
\text { of the seller / Technical knowledge of the seller's } \\
\text { insurances }\end{array}$ \\
\hline & Marketing structure & $\begin{array}{l}\text { Giving continuous training to marketers / amount of } \\
\text { advertising / type of advertising / theory and marketing of } \\
\text { market share/Advertising effectiveness / Creating a } \\
\text { marketing clinic }\end{array}$ \\
\hline \multirow[t]{3}{*}{$\begin{array}{l}\text { Insurance } \\
\text { performance }\end{array}$} & $\begin{array}{l}\text { Representative } \\
\text { financial } \\
\text { performance }\end{array}$ & $\begin{array}{l}\text { Amount of loss ratio / Portfolio amount / Portfolio } \\
\text { attraction / Timely payment of installments / Debt of non- } \\
\text { representative / Timely receipt of receivables / }\end{array}$ \\
\hline & $\begin{array}{l}\text { Representative } \\
\text { service performance }\end{array}$ & $\begin{array}{l}\text { Renewal of previous insurance policies / Having work } \\
\text { order / Renewal of insurance policy / Insurers 'satisfaction } \\
\text { / Customer loyalty / Customer orientation / Insurers' } \\
\text { feedback/ Customer Feedback }\end{array}$ \\
\hline & $\begin{array}{l}\text { Representative } \\
\text { communication } \\
\text { function }\end{array}$ & $\begin{array}{l}\text { Business relationship between the insurer and the } \\
\text { representative / how the technical managers of the } \\
\text { companies interact }\end{array}$ \\
\hline $\begin{array}{l}\text { Factors related to the } \\
\text { insurance company }\end{array}$ & $\begin{array}{l}\text { Characteristics of the } \\
\text { insurance company }\end{array}$ & $\begin{array}{l}\text { Wealth of the company / Technical knowledge of } \\
\text { managers / Knowledge of people from the insurance } \\
\text { company / Establishment of sales organization in the } \\
\text { insurance company / Use of sales network }\end{array}$ \\
\hline \multirow[t]{5}{*}{ Environmental features } & Economic factors & $\begin{array}{l}\text { Economic environment / economic issues / inflation / } \\
\text { economic recession }\end{array}$ \\
\hline & Political factors & $\begin{array}{l}\text { Political environment / political issues / government } \\
\text { policies / taxes }\end{array}$ \\
\hline & cultural factors & $\begin{array}{l}\text { Accompanying top managers and representatives with } \\
\text { sales organization / cultural issues / insurance penetration } \\
\text { in society / increasing insurance culture }\end{array}$ \\
\hline & social factors & Social environment / social issues \\
\hline & Legal factors & Legal issues and legislation of the country \\
\hline $\begin{array}{ll}\text { Sales } & \text { network } \\
\text { performance } & \end{array}$ & $\begin{array}{l}\text { performance } \\
\text { evaluation }\end{array}$ & $\mathrm{p}$ \\
\hline
\end{tabular}

However, the results related to the function of the tail of the "axial coding” stage or the “axial coding paradigm” in which 13 categories emerged during the research (Table 4-41) in the form of defined categories or categories and the recommended foundation data method is 
organized around a core category to explain the performance of the sales network in the insurance industry. These categories are described in Figure 1.

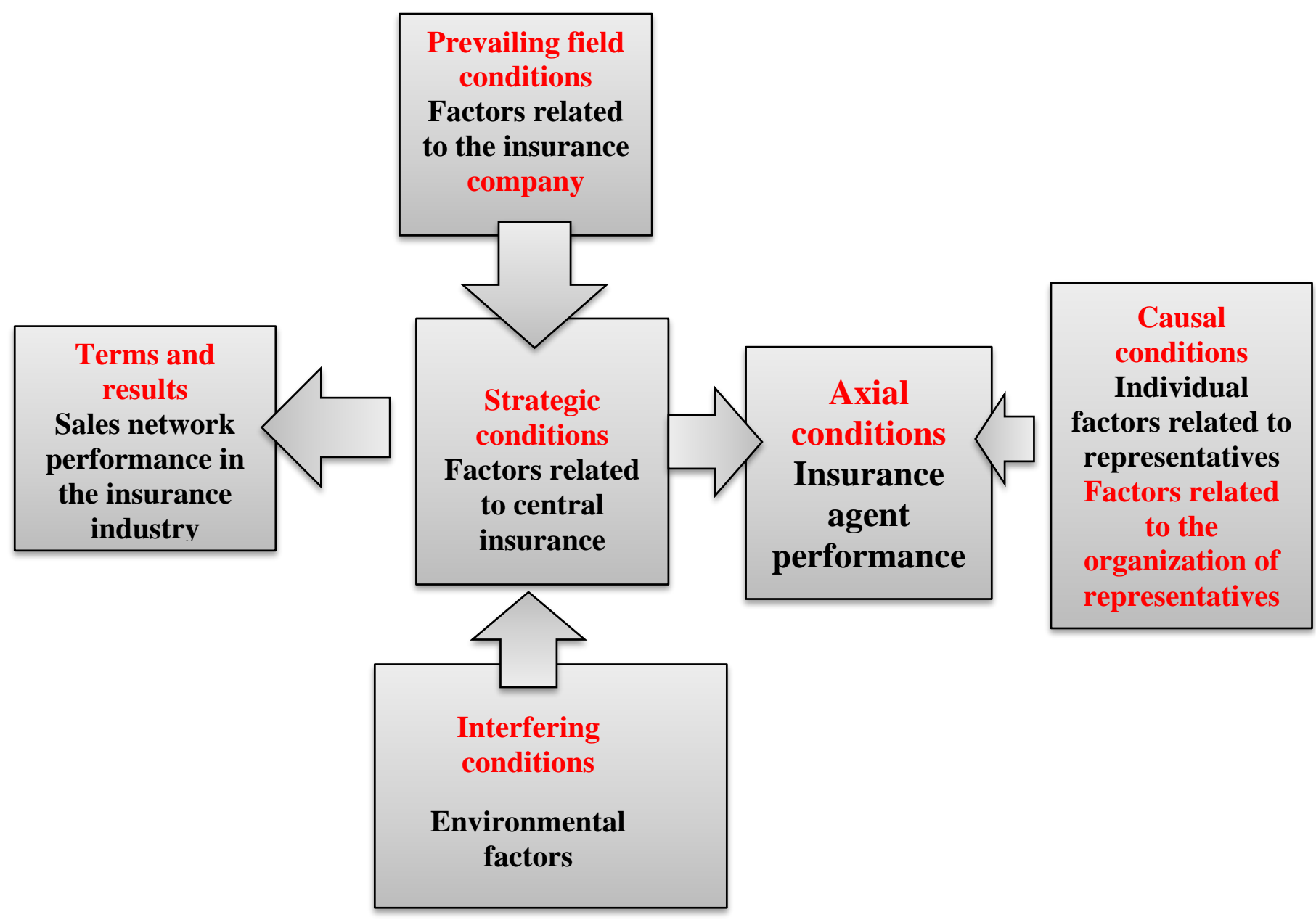

Fig 2

Sales network in the Iranian insurance industry model

\section{Discussion}

In explaining the research results in the first part and examining the causal conditions, the low sales of agents can be attributed to their individual and organizational factors. At the individual level, most delegates seem to have low morale and motivation to continue. Since these two factors are the main motivator for starting and taking any action, including marketing and selling insurance, therefore, a large part of the promotion and training program for sales network representatives should be designed and compiled with an emphasis on these factors. On the other hand, most agents do not have the skills, techniques and techniques to market and 
sell insurance (Daare, 2016). Some of the shortcomings are related to technical and specialized knowledge related to different types of insurance fields (Residential, commercial and industrial fire insurance; liability insurance; engineering insurance; complementary health insurance; third party and body insurance; life and group and individual accident insurance, etc.) (Ayuso et al, 2011). Therefore, it is necessary to prepare and compile another part of the development and promotion programs of the representatives with emphasis on these structures. Regarding the relationship between the structural and organizational characteristics of the agents and the sales performance statistics of their insurance policies, it should be noted that; In recent years, due to the intensification between insurance companies and insurance agents, the impact of organizational factors such as office space and appearance, Preparing and compiling programs in order to collect data related to insurers, manage relations with insurers, establish long-term relationships with insurers and effective advertising, the ability to plan and set goals etc., on the performance of agents has become inevitable. As a result, a significant portion of the sales network capacity development and enhancement program should be designed and developed with an emphasis on these parameters (Ismailpour, 2018).

But in the pivotal description and how the insurance agent works, the research results have shown that; Psychological and behavioral factors have been the most common in previous studies and have received the most attention. In fact, the study focuses on empowering human resources active in the insurance sales industry (Saburabani, 2019). In explaining these results, it can be stated that; Insurers act by empowering employees and related sales representatives to encourage them to take action without pressure, to respect the collective interests of the organization with minimal oversight, and to perform their duties as owners of the organization (Altuntas, 2017).

Empowerment enables insurance industry resellers to have greater resilience and flexibility in the face of problems and threats. Therefore, it can be useful as a source to prevent their vulnerability and sow the seeds of hope in them in critical situations, including the destruction of financial capital and the loss of human life. The results of the study are in line with the results of Meskin-Nawaz and Ghorbani (2017). Efficient and capable human resources are the most valuable assets and the main competitive advantage of an organization. As other depleted resources and technologies become obsolete rapidly in the current challenging environment, human resource empowerment can be a superior option to ensure the survival of the organization and keep it leading. Safari and Moradi (2017) have also confirmed that; In today's society, the sales representative of the insurance industry must have full scientific and personal capabilities and today's society cannot accept a representative who just in his office 
waiting for people to pass in front of the office door in the hope that someone enters the office as an insurer and buys insurance. According to research results, psychological empowerment is a priority. This article also confirms the results of Garrett and Gopalakrishna (2017) to form a sales team; the right team members help the performance to have a high level of psychological ability.

In explaining the intervening conditions, environmental factors, it can be stated that; identifying the market, identifying its diverse needs, and identifying customers are all part of basic marketing skills. In the past, due to the limited number of insurance companies, the job of an agent was considered a lucrative business because after a while, the seller will have a reliable base of customers and business was cumulative in nature that is, the seller, while enjoying the existing customers, if he succeeds in attracting new customers, he will benefit from the accumulated incomes of the previous years in addition to the present incomes. For this reason, many applicants for insurance sales often describe this activity as low-cost and high-income (Khodadahosseini et al, 2011). However, operating in today's highly competitive market requires the acquisition of individual and social competencies and skills for the representative and his company. This may extend the life of an insured seller. Insurers are also very aware of the past and due to the minimal cost of changing the provider of insurance services, in different years they are easily transferred from one seller to another insurer.

Insurance managers in various disciplines develop executive instructions and directives and operational strategies. Incorrect information about the situation of the insurance market in different fields and sectors and lack of familiarity with the limitations and facilities of the company's sales network, leads to the issuance of impractical orders and incorrect expectations from the sales network and this will have many destructive effects on advancing the company's market development goals (Groza et al, 2016). Operating in such an environment frustrates the representative of the company's support in providing services; finally, the representative will be inactive and limited to some compulsory insurance policies.

\section{Conclusion}

The limited marketing resources and technical capability of some insurance companies have limited them to operating in a particular market segment or discipline, which reduces the competitiveness of their agents. In particular, in areas where the insurance company's set of proposals is not compatible with the local and economic conditions of the region, the result of the representative's non-organizational activities and the provision of insurance policies to active partners in other companies. 
The result will be a reduction in the sense of organizational belonging and belonging to the parent company brand. Regarding non-compulsory insurance, the most important problem in the market is the lack of a professional sales network. After years of private insurance, the insurance industry has not yet been able to establish a proper structure and sales network for professionals and specialists. The second challenge in this area is after-sales service, which in the country's insurance industry is limited to the issue of compensation.

\section{References}

Abbasi, M. R., \& Saboor, S. (2011). The effect of internal marketing on customer orientation in the insurance industry (Case study: insurance companies in Tehran). Quarterly Journal of Insurance Research, 26(2), 67-78. https://www.sid.ir/fa/journal/ViewPaper.aspx?id=149975

Akbari, M., Al Taha, S., Farkhondeh, M., \& Pourrajbi, A. (2016). The effect of the role characteristics and individual factors of the seller on the performance of sales forces: A case study of Pasargad insurance agencies in Guilan province. Journal of Insurance Research, 1(2), 143-115. 10.22054/irisk.2019.11689.1007

Almajali, A. Y., Alamro, S. A., \& Al-Soub, Y. Z. (2012). Factors affecting the financial performance of Jordanian insurance companies listed at Amman Stock Exchange. Journal of Management research, 4(2), 266-276. 10.22056/jir.2016.47357.1705

Altuntas, M., \& Rauch, J. (2017). Concentration and financial stability in the property-liability insurance sector: global evidence. The Journal of Risk Finance, 18(3), 284-302. https://doi.org/10.1108/JRF-10-2016-0128

Asadi, A., \& Hedayati Beland, M. (2019). The effect of the quality of insurance services on the intention to buy life and investment insurance with the mediating role of previous purchasing experiences in an insurance company. Journal of Insurance Research, 34(2), 72-87. 10.22056/jir.2019.103426

Ayuso, M., Bolancé, C., \& Guillen, M. (2011). Loss Risk Through Fraud in Car Insurance. XREAP No. 2011-07, Available at SSRN: https://ssrn.com/abstract=1857007 or http://dx.doi.org/10.2139/ssrn.1857007

Busquets, J., Rodon, J., \& Wareham, J. (2009). Adaptability in smart business networks: An exploratory case in the insurance industry. Decision Support Systems, 47(4), 287-296. https://doi.org/10.1016/j.dss.2009.05.006 
Daare, W. J. (2016). Determinants of Non-Life insurance companies’ profitability: an empirical study in India. International Journal of Innovative Research and Advanced Studies, 3(13), 6-11. Retrieved from: http://www.ijiras.com/2016/Vol_3-Issue_13/paper_2.pdf

Desai, D. (2016). An analytical study on retention of financial planning advisors at Aviva Life Insurance, Pune, Maharashtra, India. ZENITH International Journal of Business Economics \& Management Research, 6(3), 41-53. https://www.indianjournals.com/ijor.aspx?target=ijor:zijbemr\&volume=6\&issue=3\&a rticle $=004$

Garrett, J., \& Gopalakrishna, S. (2017). Sales team formation: The right team member helps performance. Industrial Marketing Management, 77, 13-22. https://doi.org/10.1016/j.indmarman.2017.06.007

Groza, M. D., Locander, D. A., \& Howlett, C. H. (2016). Linking thinking styles to sales performance: The importance of creativity and subjective knowledge. Journal of Business Research, 69(10), 4185-4193. https://doi.org/10.1016/j.jbusres.2016.03.006

Heikli, L., Qaderzadeh, D. (2017). Indexing Certificate of Article Explaining the Relationship between Job Security and Job Performance in Representatives of Insurance Companies, Quarterly Journal of New Research in Management and Accounting, 7(3), 34-50. https://www.inderscience.com/info/ingeneral/forthcoming.php?jcode=ijbg

Huang, Y., Vemer, P. Zhu, J. Postma, M.J. \& Chen, W. (2016). Economic burden in Chinese patients with diabetes mellitus using electronic insurance claims data. PLoS One, 11(8): e0159297. https://doi.org/10.1371/journal.pone.0159297

Ismailpour, R., \& Qasemnejad, M. (2018). Developing a social marketing model for insurance companies. Business Management, 10(1), 31-48. doi: 10.22059/jibm.2018.228575.2510. 10.22059/jibm.2018.228575.2510

Kafashpour, A.,Mortazavi, S., \& Mehrafrooz, M.(2013). The role of moderating sales skills in the impact of sales orientation and customer orientation on the performance of the sales force of insurance companies. Journal of Marketing Research, 32(9), 108-87. http://nmrj.ui.ac.ir/article_17650.html

Karegar, E., Rahmati Nodehi, R., \& Sabzi, M. (2014). Empowering human resources of organization and insurance selling network with effective factors approach. European Online Journal of Natural and Social Sciences, 2(3), 2902-2918. https://hrmj.ihu.ac.ir/ Khodadahosseini, S., Daqiqi Asli, A., Rajabzadeh, A., \& Mokhtari, M. (2011). Designing the efficiency model of life insurance sales network (Study of Iran 
Insurance Company by Data Envelopment Analysis (DEA), M.Sc. Thesis, Tarbiat Modares University, Iran.

Maroofi, F., Ardalan, A. G., \& Tabarzadi, J. (2017). The effect of sales strategies in the financial performance of insurance companies. International Journal of Asian Social Science, 7(2), 150-160. https://ideas.repec.org/a/asi/ijoass/2017p150-160.html

Onyango, J. A. (2017). Motivational Strategies and Sales Force Performance in the Insurance Industry in Kenya. Doctoral dissertation, United States International University-Africa.

Panagopoulos, N. G., \& Ogilvie, J. (2015). Can salespeople lead themselves? Thought selfleadership strategies and their influence on sales performance. Industrial Marketing Management, 47, 190-203. https://doi.org/10.1016/j.indmarman.2015.02.043

Rezaei, F., \& Ahmadi, Z. (2012). Evaluating the performance of modern insurance branches using BSC and Topsis model. Transformation Development Management Quarterly, 10, 39-31. http://www.jdem.ir/article_380.html

Saburabani, E., \& Khashei, V. (2019). Modeling evidence-based strategic decision making in the insurance industry based on data theory. Business Management Quarterly, 11 (42), 782-803. 10.22059/jibm.2019.271838.3367

Safari, S., Moradi Doliskani, S., \& Raisi Ghorbanabadi, H. (2017). Providing a framework for evaluating the performance and ranking of insurance companies with a multi-criteria decision-making approach (enriched perimeter method). Insurance Research Journal, 32(1), 22-32. 10.22056/jir.2016.49743.1740

Sehat, S., Khatami Firoozabadi, A., \& Mirzaei Bani, M. (2011). Evaluating the performance of insurance companies' agencies using a combination of organizational excellence indicators and data envelopment analysis method. Master Thesis in Management, Allameh Tabatabaei University, Iran.

Shen, K. Y., Hu, S. K., \& Tzeng, G. H. (2017). Financial modeling and improvement planning for the life insurance industry by using a rough knowledge-based hybrid MCDM model. Information Sciences, 375, 296-313. https://dl.acm.org/doi/abs/10.1016/j.ins.2016.09.055

Stoeckli, E., Dremel, C., \& Uebernickel, F. (2018). Exploring characteristics and transformational capabilities of InsurTech innovations to understand insurance value creation in a digital world. Electronic Markets, 28, 287-305. https://doi.org/10.1007/s12525-018-0304-7 
Wang, P. (2014). Government intervention and the empowerment process: citizen involvement in the 2010 Shanghai world expo. Journal of Public Affairs, 14(2), 130-141. https://doi.org/10.1002/pa.1517

Wijayanti, S. K., \& Ramsay, B. (2016). Life Insurance Take-Up Rate Influencing Factors Comparison between Malaysia and Japan. International Journal of Business and Social Research, 6(7), 37-41. https://ideas.repec.org/a/lrc/larijb/v6y2016i7p37-41.html

Yaisawarng, S., Asavadachanukorn, P., \& Yaisawarng, S. (2014). Efficiency and productivity in the Thai non-life insurance industry. Journal of productivity analysis, 41(2), 291306. DOI: 10.1007/s11123-012-0317-8 